\title{
Identity of Muslims in India as Marginalized community: Special Focus on Minorities of Gujarat State
}

\author{
Salu Dsouza \\ \{saludsouza@yahoo.com\} \\ School of Law, Christ (Deemed University),India
}

\begin{abstract}
Marginalized communities and ethnic minorities are a visible sign in most of the modern societies around the world. The tag people carry as belonging to a marginalized and minority community may give rise to suspicion. Their presence in a civilized society may not be welcomed and the people who belong to majority communities may not reckon them. However, in India, the constitution has recognized the rights of people who belong to marginalized and minority communities. Over the years, the majority has curtailed the rights of the marginalized communities' not through legislation but by depriving them of government benefits. The constitution of India has safeguarded the identity of minority population. Jains, Sikhs, Christians, Buddhists, Parsis and Muslims as minorities have to live among the people who are in majority communities. Among these six minority communities, Muslims across the world and in India are looked in suspicion. Most of the communal violence across India have had the participation of Muslims. Do these people involve in violence without any provocation? The Sachar Committee, which was appointed to look into social, economic and educational conditions of Muslims, highlighted and presented its suggestions on how to remove impediments preventing Indian Muslims from fully participating in the mainstream activities of Indian life. On this background, my research paper tries to show the conditions of Muslims as belonging to one of the minority communities in India, how have they been marginalized, their present status in the state of Gujarat and their contributions to the nation building tasks.
\end{abstract}

Keywords: Minority; backlash; Muslims; marginalise; education; nation; rights; community; communal

\section{Introduction}

Muslims in India have been living in different areas for many years. They were given an opportunity to move to newly created country during the time of partition. However, many Muslims preferred to live in India than shifting their bases to Pakistan after partition. The lack of transportation and the location that South India was too far away to North Indian towns during the partition period made the Muslim population of Southern Indian towns to remain in India. The constitutional rights in India made the Muslim population to work for the nation building tasks rather than thinking of moving out from India to Pakistan.

Living in India for many years, under various rulers, Muslims have been accorded various positions and designations even in British India and later during the independent India has 
given protection to this minority community in the constitution of India. The lawmakers and the framers of constitution of India had accepted the role that the Muslim population had played in the construction of India through their diversified identities. The main idea behind this is a highly educated Muslim could decorate the highest constitutional position in India.

\section{Identity Crisis}

Muslims in India have been in different occupational strata. There are civil servants, judicial officers, and professionals like doctors, engineers, teachers and religious leaders. Farmers and street vendors contribute in the task of nation building where everyone gets the fruits of their hard labor. Muslims do not recoil themselves in one locality. They are integrated and assimilated in the very fabric of Indian ethos. Their diversified identities can be seen in Indian context as Tamil speaking Muslims in Southern state of Tamil Nadu to that of Kashmiri and Dogri speaking Muslims in Jammu and Kashmir. The western Indian side we find Gujarati speaking Muslims and in Eastern side of India they are identified as Bengali Muslims in the state of West Bengal. However, their identities cannot be affiliated only to those who speak in Urdu and Hindi. However, these two languages spoken widely by Muslims across Indian subcontinent, there are Muslims who identify themselves as belonging to a particular state, its culture and language and broadly, they identify themselves as Indian.

Let us consider the following questions, though Muslims in India identify as belonging to India, the majority community still look at them in suspicious eyes. What is the reason for this? Why does the suspicion emanate though these Muslims ancestors were born and died in the Indian sub-continent? Is the reason that their faith has come from a foreign country enough to justify that they are not truly Indian? It is true that their faith has come from a foreign country but they have nothing to do with that country since they have professed their loyalty towards India. It would be better and wise decision from other communities to accept the diversified nature of Muslim population in India, try to educate their siblings and make them as productive citizens of India who are ever ready to sacrifice their lives to the cause of nation rather than sowing the seeds of mistrust and misunderstanding in their diversified identities.

While writing an article to The Hindu newspaper, Hilal Ahmed, a faculty member at CSDS opines, "It is important to note that although Islam as a religion provides a unifying religious identity to various Indian Muslim communities, Muslims tend to follow various sect-based interpretations of religious texts and region-based rituals and customs. It is this religiouscultural distinctiveness, which makes Indian Islam a highly diversified phenomenon. The question of politics, especially electoral politics, is inextricably linked to this unique Muslim diversity." (The Hindu, 24 July 2016).

Further analysis on this shows that the Muslims tend to follow the identity of the domicile region in the state rather than their unique identity as belonging to the religion of Islam. A Muslim from any country from the Middle East coming to India may conclude as 'gone astray' after seeing the local culture where Muslims of that region who have assimilated into the local cultural ethos follow the culture of that place. How far Muslims in India are secure in this secular democratic set up? Over the years, the militancy in Kashmir region has seen the active participation of Muslims and their active cells in different parts of India that has done a lot of damage towards the community. The suspicion has become more severe soon after the terrorist attacks indifferent parts of India. Communal violence in few parts of Uttar Pradesh and a coastal town in Karnataka, the concept of Love Jihad, which was in vogue in parts 
Kerala and other incidents have been playing on the psyche of the Hindu fundamentalists who have openly commented on the nature of Muslims in India.

The Godhra carnage that gained the attention of the world community, thereafter, the aftermath of this incident where a large number of Muslims were torched in Ahmedabad and elsewhere in Gujarat kept the Muslim population away from the dwellings of majority community. The implication of being a Muslim in India is challenging. C.M. Naim, while writing to Columbia edu portal says, "Being a Muslim in India is at the same time a challenge and an opportunity: to become functionally alive in the developing, secular democracy. I suggest that a way to meet that challenge is for the Muslims to discover their own individual, highly differentiated pasts and only then to engage in making aggregates of them, first at the local and regional levels, and later at the national level." (C.M. Naim, for Columbia edu portal).

Keeping this statement in mind, there are Muslims who are active in local politics in Gujarat. The district of Anand, an hour journey from Ahmedabad has housed a large number of Muslims. There are businesspersons. Fighting local Panchayat elections was not new to these Muslims. They have been in support of congress leaders in Anand district, which had traditionally remained faithful to congress party ideology

\section{Muslims in Gujarat State}

The state of Gujarat is known for its cultural values and new development model. Gujaratis are enterprising who have gone to different countries and the business diaspora sends huge remittances to Gujarat. The early migrants from Gujarat to African coasts were Gujarati Hindus and Muslims. Dawoodi Bohra and Khojas who are prominent business communities in Gujarat have set their foot in various countries. Bhora style of Mosque construction is still visible in Gujarat (Madhavi Desai, 1992). It is estimated, more than 50\% of Dawoodi Bora community Muslims reside in Gujarat (Asghar Ali Engineer, 1980). Over all, Gujarat state has Muslim population with diversified identities such as a lot of difference can be seen in their social strata, some are rich and others are poor, some are educated with good jobs but others are doing menial jobs.

Among Hindu upper castes, the Patel community has large landholdings across Gujarat, monopolized agricultural activities. They have interests in politics, business, industries and educational institutions. Among OBCs, Thakor community comes behind the Patels in the above said activities. Dalits are in less number when compared to Scheduled tribes. Population of Christians is lesser than Muslims. Among all the minority communities in Gujarat, Muslims have a larger population share. Its total population is $9.67 \%$ and Christians account just $0.52 \%$. Before the Patel agitation for OBC quota, people did not bother about Muslim support. However, 'Gujarat Kshatriya-Thakor Sena' president Alpesh Thakor once commented by saying, "These general castes projected Muslims as our enemies and incited OBCs to fight against them. But now we have learnt that Muslims are also OBCs. They are among us. We have now realized that our actual enemies are those who want to snatch our right of reservation," he said. (Indian Express, 23 August 2015).

Soon after the Patel agitation in the state, most of the OBCs came together to protect their reservation rights. Later, the lynching of Dalits brought Dalit communities together under Jignesh Mevani who is the present leader of Rashtriya Dalit Adhikar Manch. In the prevailing scenario, we can see in Gujarat Hindu OBCs, Muslims and Dalits have come together to form a grand alliance against the upper castes. The assembly election that is going to take place in the months of November - December 2017 will have an interesting contest from different 
sections of the society. Muslims in Gujarat though politically not active but can be a reckoning force by financing the candidates whom they could see potential winners and their sympathizers. Having glorified the Patel community within Gujarat and the Patels in Indian diaspora, it is also interesting to see how upper castes of Gujarati people have kept the population that is considered "Other", out of the preview of benefitting from "Gujarat Model of Development". The OBCs especially who belong to Hindu religion had slight better treatment than that of Muslims, Christians and Scheduled Castes.

Reverend Father Cedric Prakash, a Jesuit Catholic Priest, based in Ahmedabad was a champion of fighting against injustice towards the SCs, STs, Muslims and Christians. He was in charge of an NGO. While speaking on the issue of Anti-Conversion legislation, in his article, "Ruthless and regular persecution of Gujarat's Christians and Muslims", comments, "The government of Gujarat "has conveniently forgotten that Article 25 of the Constitution guarantees freedom of worship, and it does everything in its power to continue, and to justify, ruthless persecution against Christians and Muslims living in the state". With these words, Fr Cedric Prakash - director of Prashant, a Jesuit-run centre for human rights, justice and peace concluded the article he wrote about the "Carnage of Gujarat": the massacre perpetrated three years ago by "unknown people" against the Muslim community." (Fr. Cedric Prakash, 2006: Asia news web portal).

This has shown that the anti-conversion law is a step forward by the upper castes to make Gujarat as a "fully populated by Hindus" as commented by Praveen Togadia (Praveen Togadia warns Muslim family, India TV News Desk, 2014). Further Fr. Prakash spoke on the issue of harassment meted out to Muslims and Christians. The anti-conversion law plays its major role when a Hindu converts to Islam, Christianity or Judaism than to that of Jainism, Buddhism and Sikhism. He opined, ".....the government continues to harass and intimidate Christians, Muslims and other minorities with a terrifying regularity. They are doing all in their power in order to justify this law and persecution. The government has conveniently forgotten that Article 25 of the Constitution guarantees every single citizen, the freedom to practice, preach and propagate the religion of his/her choice." (Fr. Cedric Prakash, 2006: Asia news web portal).

Muslims were asked to vacate the houses by VHP, RSS members who have their membership in Patel communities. When Praveen Togadia had come to Gujarat, he openly poured venom on Muslim communities, like, "A Muslim businessman had never thought while buying a bungalow in a posh area of Bhavnagar city that he will not be allowed to move in. Hindu Sanatorium-is the address given by local residents in a section of Krishna Nagar, a posh area of Bhavnagar city. A Bohra Muslim, Ali Asghar Zaveri, in January this year, had purchased a bungalow but he has not been able to move in due to protests by Hindu residents, according to a report published in Indian Express. For the last two months, the Hindu residents have been holding "Ram Darbars" outside Zaveri's bungalow every evening, gathering there and playing recordings of "Hanuman Chalisa" and bhajans. VHP leader Pravin Togadia visited the area during the darbar on Saturday. Addressing the gathering, he reportedly warned Zaveri to vacate the premises within 48 hours and asked residents to forcibly occupy the bungalow. An FIR has been filed against him. The bungalow next to Zaveri's belongs to the family of Razak Lakhani. While Lakhani is dead, his family continues to live there." (India TV News web portal: 23 April 2014).

The above statement of a VHP prominent figure in Gujarat had threatened and frightened the Muslims who are destitute and poor. If Patels wish, they could have protected this man from harassment but they did not. The majority community looks down not all the Muslims in Gujarat. Educated Muslim population are in decent jobs. There are rich Muslims doing brisk 
businesses. Many of the Gujarati Muslims have settled in Mumbai and doing well in their chosen field of work. Mahatma Gandhi got an invitation from a Gujarati Muslim who was working in South Africa. This incident made Gandhi to embark upon African tour, ended up in South Africa fighting for the causes of Africans, and marginalized Indian diaspora of that time.

In spite of the backlashes, atrocities, harassments and depriving of opportunities to Muslims in India general and Gujarat in particular, they are working silently in every field. In many places, their Hindu brethren from majority community would vouch for their nationalistic commitments, security and patriotism. Muslims in India have been working towards the nation building tasks in their own ways. They support Shri Narendra Modi's call towards good governance and development of India. There are engineers, doctors, civil servants, teachers and other professionals from Muslim community working hand in hand with their fellow citizens.

At school, colleges and universities Muslim teachers mould students thinking capacity and assist them to become useful citizens of India. Muslims of India today are ready to lay down their lives for the sake of their nation. Their loyalty is for their homeland, which is India. However, it is not right on the part of bigots asking them to prove their nationalistic feelings. Some statements uttered in public against the Muslim communities in India may dampen their spirit. Keeping the sensitive issues in mind, it is advisable for the responsible citizens to avoid issuing statements that would hasten the communal violence. Never in India, should majority community doubt about the integrity of Muslims of India. Appreciation of their diversified identities, culture and tradition is the need of the hour.

\section{Conclusion}

The majority community in certain parts of Gujarat do not want to see the minority settling down. One can see a stark contrast in Gujarat. People of Gujarat no doubt are enterprising in nature. Their wealth has been increasing. Their religious beliefs too are increasing. At the same time, their love for cows also increases day by day. They feed street dogs with Parle - G, Marie and Crack Jack biscuits. They throw grains at birds. They have kept fodder for cattle stock. They regularly put sugar to ants. They also take regular insulin injection for their ailment. A lot of charity work is done in Gujarat. There are many NGOs working with the active financial and logistical support from Gujarati Diaspora. It is a well-known fact that Gujaratis earn well and spend well. This helps the economy moving. If one travels inside Gujarat, progressive areas and backward areas can be seen. There are many Hindu religious places frequented by the faithful spending huge amount on religious festivals. Does this bring any change in their attitude towards the marginalized sections of the society? Haven't foreign returned Gujaratis observed how foreign people treat Muslims and other ethnic communities in their countries? Gujarati majority population should be broadminded in accommodating all classes of people in Gujarati society.

Patels are rich in every aspect. The major contrast in Gujarat, one can ask, how do Gujaratis treat human beings? How minorities are treated in Gujarat? What is the status of Muslims in Gujarat? If upper caste Hindus of Gujarat want to make Gujarat as a fully inhabited land by Hindus, then where should the minorities particularly Muslims and Christians go? When we say Gujarat is a developing state, we need to stop and ask a question, is it all-inclusive? If it is not inclusive growth then who are left out? Do people who have really toiled get recognition? Dominant class should see that even the marginalized section of 
the society and the minority population such as Muslims should get good and reasonable price for the hard labour that they put in every day.

The state has its name and fame in the world map. Let not discrimination among castes and religions stultify the glory and pride of Gujarat. There are enough indications of bickering in the unity of the people in Gujarat. Visible cracking signs in Gujarat Model of Development have already shown not only in Gujarat and India but also for the world community. The incident like that of Godhra and its aftermath reaction should have taught a lesson to all those who perpetuate violence and atrocities on minority communities. The progress of Gujarat state lies with every stakeholder who has really toiled to make this state progressive. Let the rich culture of Gujarat should hold Gujarati Muslims within the inclusive growth without any regional imbalances and the Gujarat model of development flourish in Gujarat by taking along with its journey towards development, progress and good governance.

The majority community across India should understand the history of Muslims. However, the partition of India gave a chance to Muslims to shift their bases towards newly created Pakistan, a large number of Muslims decided to stay back in India and work for nation building task. They did not fail the dream of India. There are many Muslims, in spite of having diversified identities, have got highest education and decorated the highest constitutional position in India. A vast number of businesspersons have been doing philanthropic work in different fields. There are many educational institutions managed by Muslims in India. Gujarati Muslims are entrepreneurs, doing social work along with their brethren from majority communities. This kind of relationship should prosper that would remove the mistrust and misunderstanding between communities.

\section{References}

[1] Bhikhu, Parekh. (2004). Limits of the Indian Political Imagination. London: Sage Publications. Desai, Madhavi. Traditional house form of Bohras in Gujarat: Architectural response to cultural ethos. [Report 1992].

[2] Engineer, Asghar Ali (1980). The Bohras of Sahidabad. New Delhi: Vikas Publishing House Pvt. Ltd.

[3] http://www.thehindu.com/opinion/op-ed/a-diversified-muslim-identity/article5851881.ece (Accessed 3 May 2019).

[4] http://www.asianews.it/news-en/Ruthless-and-regular-persecution-of-Gujarat's-Christians-andMuslims-5755.html (Accessed 21 April 2019).

[5] http://www.hindustantimes.com/india/community-power-how-the-patels-hold-sway-overgujarat/story-WejgSajNL5YcxA3rUf8ajK.html (Accessed 8 June 2019).

[6] http://www.columbia.edu/itc/mealac/pritchett/00litlinks/naim/ambiguities/07beingamuslim.html (C.M. Naim, accessed 12 June 2019).

[7] http://www.indiatvnews.com/news/india/bhavnagar-pravin-togadia-warns-muslim-family-tovacate-the-prem-35757.html (Accessed 29 May 2019).

[8] http://indianexpress.com/article/india/gujarat/obcs-threaten-to-uproot-gujarat-government-ifpatels-given-reservation/ (Retrieved, 11 June 2019). 